\title{
Forum
}

\section{The social and environmental impacts of wilderness and development}

\author{
Dan Brockington and Kai Schmidt-Soltau
}

Sanderson \& Redford's (2003) correct insistence that poverty alleviation programmes ought more actively to include conservation would be well matched by an awareness of the impacts of some conservation policies, particularly the establishment of strictly protected areas, on local livelihoods. Lands protected as wilderness require the removal or exclusion of people and are locally costly. Wilderness protection requires, we argue, far more awareness of the nature and extent of these costs wherever conservation interests have to be served by people's absence.

Poverty alleviation that overlooks conservation is not sustainable and will offer no relief to threats to biodiversity. For several years now biological scientists and conservationists have reminded us that Millennium Development Goals, poverty reduction strategies and the latest trends in sustainable development have to pay due regard to conservation priorities. Failure to strike the right balance between conservation and development is dangerous to conservation, and quite possibly deleterious to human development.

The converse is also true: if conservationists get the balance wrong, with environmental policies ignoring the impoverishment that they may cause, then the result is certainly harmful to people and quite possibly damaging for conservation. This is most clearly apparent with the social impacts of strictly protected areas (IUCN categories I and II). The international conservation community at the World Parks Congress has voiced in the Durban Accord the concern 'that many costs of protected areas are borne locally - particularly by poor communities while the benefits accrue globally' (WPC, 2003). The Congress made the commitment, 'that protected area management strives to reduce, and in no way exacerbates, poverty' (WPC, 2003).

Since the inception of national parks, the protection of perceived wildernesses has necessitated the removal of people. Some more recent parks have involved careful compensation arrangements for people evicted, but these are not the norm. More often, evictions occasion expense,

Dan Brockington (Corresponding author) School of Geography and the Environment, University of Oxford, Mansfield Rd, Oxford, OX1 3TB, UK. E-mail dan.brockington@geography.oxford.ac.uk

Kai Schmidt-Soltau P.O. Box 7414, Yaoundé, Cameroon.

Received 20 January 2004. Accepted 9 February 2004. hardship and impoverishment. Assessments of biodiversity conservation in the context of poverty alleviation suggest that protected areas do not reduce poverty, but on the contrary increase the poverty of rural populations (Brockington, 2002, Cernea \& Schmidt-Soltau, 2003). Compensation for the impoverishment caused by protected areas requires knowledge of who has been affected and how greatly their lives have changed. Appreciation of the multiple benefits of conservation for biodiversity and for people will be incomplete without a good understanding of the costs involved.

In our view, wilderness and protected area policies require a far greater understanding of their social and environmental impacts, for five reasons. Firstly, there is a widespread recognition that protected areas which cause harm or inconvenience to local groups will be threatened by non-cooperation or outright resistance. State authorities and conservation organizations are striving to find ways in which protected areas can provide real benefits to local groups. They are handicapped by want of measurement and understanding of the costs involved. It is therefore hard to tell whether the benefits offered provide adequate compensation for the inconvenience conservation can cause. Similarly, engagement between conservation authorities and local communities is often handicapped by inadequate grasp of the history of interaction and conflict between the two. This has to be recognized as part of any process of rapprochement. To find a balance between local people's needs and protected areas requires careful and detailed data collection.

Secondly, addressing the costs of conservation is important for more than just the pragmatic reasons that not doing so may harm conservation. There may be instances where it will be possible for conservation policies to disadvantage local people without compromising their own objectives. Rural groups may be too weak to effectively resist and obstruct conservation (Brockington, 2003). But there are powerful ethical reasons why the power of conservation policies should not be wielded in this way, in the same way as the power of the poverty reduction paradigm should not ignore the needs of biodiversity protection.

Thirdly, conservation can and should be a powerful tool for wealth creation and poverty reduction. The potential for conservation agendas to empower and enrich local groups is recognized in many quarters. Protected areas in particular can have many positive 
benefits for local groups, including provision of ecosystem services, employment opportunities, and preservation of cultures. Yet the full impact of these schemes requires a good understanding of their impacts on local peoples' livelihoods and of the opportunity costs incurred by setting aside land for conservation. The local politics and distribution of the costs and benefits within communities must also be understood if the contribution of these schemes to the common good is to be realized.

Fourthly, the abuses that some groups have suffered as a result of conservation policy has given human rights and cultural survival organizations considerable cause for concern. At the same time it is clear that many of the data they cite and examples they list are contested by their opponents. Debates tend to generate more heat than light and are often characterized by want of good data. Clearer arguments would be facilitated by better information.

Fifthly, despite the gains made for protected areas in recent years there are still biodiversity hotspots and areas of important habitat that are not adequately protected. National governments and international conservation organizations are seeking to expand the area of conservation estate to meet these needs. To be undertaken properly this will have to involve good assessments of the costs that these moves are likely to incur, and the benefits that they will bring.

But despite these imperatives and their increasing recognition within conservation, progress in dealing with them is painfully slow. They still arouse considerable resistance. Attributing the outputs of the World Parks Congress, for example, to the 'international conservation community' ignores the marked divisions in the conference between those who found these measures important and those who felt they were detracting from the proper business of conservation. This is particularly noticeable in the fact that despite a threefold increase in the number of protected areas in the last 30 years we have relatively little idea of what the social costs of that expansion has been. Here conservation is lamentably behind other fields. The consequences of land loss to dams or large scale development projects, for example, is now better recognized, and clear methodologies have been drawn up to assess the impacts (Cernea \& Guggenheim, 1996; Cernea, 1997; Mahapatra, 1999; Cernea, 2000; WCD, 2001; Downing, 2002; World Bank, 2002).

The welcome gains made for protected areas in the last generation have been accompanied by silence over its social costs (Chatty \& Colchester, 2002). This is particularly worrying where we can expect the eviction of people to be harmful to livelihoods. In the developing world many areas worthy of protection are also the home of predominantly poor rural populations. In these circumstances we should expect that eviction without provision for better livelihoods or employment will cause impoverishment.

It must be remembered that the categories of protected areas counted in the recent expansion include many places where human residence is still allowed. The area occupied by IUCN protected area categories I and II is only $30 \%$ of total protected lands. But a significant proportion of protected areas are yet to be categorized, and some of those in categories other than I and II have required the eviction and exclusion of people (Game Reserves in Tanzania, for example, which are category IV) or embody other significant negative impacts for the inhabitants of these areas (Schmidt-Soltau, 2004). The increase in protected areas over recent decades is likely to have had a considerable human cost, about which there is remarkable silence or denial in conservation circles.

In this context it is therefore disappointing that Sanderson \& Redford did not mention this aspect of the relationship between poverty and conservation, and it points perhaps to a deeper malaise at work. The fundamental conflict here might be cognitive (Adams et al, 2003). It is in the framing and awareness of the issues that problems of conservation-induced impoverishment are ignored, just as development planners and poverty alleviation strategies are turning a blind eye to conservation needs.

Recognizing the existence of both problems does not mean that both conservation and poverty alleviation can be equally provided for in any given situation. There are many cases where conservation can only proceed in the absence of people and removing them will be costly and violent. Nor will economic measures alone capture the full loss of identity, home, belonging and the other intangibles that protected areas will deny. Equally, development and the spread of human influence has had, and will continue to have, a devastating impact on habitat and species survival. Recognizing the existence of both needs will require recognizing conflicts and incompatibilities.

Development that is sensitive to conservation needs will, as Redford \& Sanderson recognize, be sensitive to local needs and the diversity of local priorities, and will prioritize livelihood change that leaves space for Nature. But it will still, on occasion, be destructive. Prioritizing conservation needs in development will not mean ceasing to transform the world, but understanding precisely what the losses to biodiversity and conservation will be. Then it will be possible to know what sort of redress is necessary, and which losses cannot be compensated for. Equally, strict protected areas that are pro-poor will not necessarily mean no more evictions. But they will be 
aware of the costs of these moves. They will actively seek to assess the full economic, cultural and psychological impacts, and they will strive adequately to compensate any losses and mitigate the damage.

Practically, we can suggest two specific priorities necessary for conservation to achieve such sensitivity. Firstly, in recognition of the power and influence wielded by international conservation organizations it will be important for them to develop codes of conduct with respect to the social impacts of the policies they support. These are analogous to the conservation codes of conduct advocated for private companies (Sanderson, 2002). These codes could, following the poverty reduction recommendation of the World Parks Congress, involve commitments not to support conservation policies that perpetrate injustices or that, for example, entail evictions without adequate compensation.

Secondly, it is imperative to have some sort of assessment of the nature of the social impact of protected areas, especially given recent expansions. This requires a substantial effort, but is easily within current capacities. We have developed a methodology for such a global assessment (Schmidt-Soltau \& Brockington, 2004), based on a sample of 196 protected areas (2\% of IUCN protected area categories I and II) that will examine the consequences of land loss, and the benefits of protected areas, based on our previous work (Brockington, 2002; Schmidt-Soltau, 2003). Its success depends on the widespread involvement of diverse regional experts, and we would welcome comments, advice and involvement. We hope it will be a means actively to address the impoverishment that conservation can cause.

Sustainability has both ecological and social dimensions. Population relocation for park creation requires this double sustainability - of livelihoods and of the biosphere. When protected area policies and resources are put in place to ensure poverty reduction through relocation for park creation, then the double sustainability would be accomplished. This is possible but relatively expensive. Estimates for such resettlement in rainforest are \$20-30 thousand per person (Cernea \& Schmidt-Soltau, 2003). Where the political will to achieve double sustainability is not available the rural population will lose and biodiversity conservation is unlikely to win local support. We agree with Sanderson \& Redford 'that the single requirement is a dedication to create ... partnerships between conservationists and developmentalists', but we insist that a reconciliation that ignores either the social or ecological costs will lead nowhere.

\section{References}

Adams, W.A., Brockington, D. Dyson, J. \& Vira, B. (2003) Managing tragedies. Understanding conflict over common pool resources. Science, 302, 1915-6.

Brockington, D. (2002) Fortress Conservation. The Preservation of the Mkomazi Game Reserve, Tanzania, James Currey, Oxford, UK.

Brockington, D. (2003) Injustice and conservation - Is 'local support' necessary for sustainable protected areas? Policy Matters, 12, 22-30.

Cernea, M.M. (1997) The risks and reconstruction model for resettling displaced populations. World Development, 25, 1569-1589.

Cernea, M.M. (2000) Risk, safeguards and reconstruction: a model for population displacement and resettlement. In Risk and Reconstruction: Experiences of Resettlers and Refugees (eds M.M. Cernea \& C. McDowell), pp. 11-55. Word Bank, Washington, DC, USA.

Cernea, M.M. \& Guggenheim, S. (1996) Resettlement and Development. The Bankwide Review of Projects Involving Involuntary Resettlement. ESSD, Resettlement Series no. 32,World Bank, Washington, DC, USA.

Cernea, M.M. \& Schmidt-Soltau, K. (2003) National Parks and Poverty Risks: Is Population Resettlement the Solution? Paper presented at the World Park Congress (Durban, September 2003). An abbreviated version was published as: The end of forced resettlements for conservation: conservation must not impoverish people. Policy Matters, 12, 42-51.

Chatty, D. \& Colchester, M. (2002) Conservation and Mobile Indigenous Peoples: Displacement, Forced Settlement and Sustainable Development. Berghahn, Oxford, UK.

Downing, T.E. (2002) Avoiding New Poverty: Mining-Induced Displacement and Resettlement. International Institute for Environment and Development and World Business Council for Sustainable Development, London, UK.

Mahapatra, L.K. (1999) Resettlement, Impoverishment and Reconstruction in India: Development for the Deprived. Vikas Publishing House, New Delhi, India.

Sanderson, S.E. (2002) The Future of Conservation. Foreign Affairs, 81, 162-173.

Sanderson, S.E. \& Redford, K. ( 2003) Contested relationships between biodiversity conservation and poverty alleviation. Oryx 37, 389-390.

Schmidt-Soltau, K. (2003) Conservation-related resettlement in Central Africa: environmental and social risks. Development and Change, 34, 525-551.

Schmidt-Soltau, K. (2004) The local costs of rainforest conservation: local responses towards integrated conservation and development projects. Journal of Contemporary African Studies (in press).

Schmidt-Soltau, K. \& Brockington, D. (2004) The Social Impacts of Protected Areas.

Http:/ /www.social-impact-of-conservation.net [accessed 12 February 2004].

WCD (2001) Dams and Development: A New Framework for Decision Making. Earthscan, London, UK.

World Bank (2002) Operational Policy 4.12: Involuntary Resettlement. World Bank, Washington, DC, USA.

WPC (World Park Congress) (2003) List of Recommendations approved at the World Parks Congress. Http:/ /www.iucn.org/themes/wcpa/wpc2003/english/ outputs/recommendations.htm [accessed 11 February 2004]. 